\title{
A tandem array of CBF/DREB1 genes is located in a major freezing tolerance QTL region on Medicago truncatula chromosome 6
}

\author{
Nadim Tayeh ${ }^{1}$, Nasser Bahrman ${ }^{1,2}$, Hélène Sellier ${ }^{2}$, Aurélie Bluteau ${ }^{1,2}$, Christelle Blassiau', Joëlle Fourment ${ }^{3}$,
} Arnaud Bellec ${ }^{3}$, Frédéric Debellé ${ }^{4}$, Isabelle Lejeune-Hénaut ${ }^{2}$ and Bruno Delbreil ${ }^{1 *}$

\begin{abstract}
Background: Freezing provokes severe yield losses to different fall-sown annual legumes. Understanding the molecular bases of freezing tolerance is of great interest for breeding programs. Medicago truncatula Gaertn. is an annual temperate forage legume that has been chosen as a model species for agronomically and economically important legume crops. The present study aimed to identify positional candidate genes for a major freezing tolerance quantitative trait locus that was previously mapped to M. truncatula chromosome 6 (Mt-FTQTL6) using the LR3 population derived from a cross between the freezing-tolerant accession F83005-5 and the freezing-sensitive accession DZA045-5.

Results: The confidence interval of Mt-FTQTL6 was narrowed down to the region comprised between markers MTIC153 and NT6054 using recombinant $F_{7}$ and $F_{8}$ lines. A bacterial-artificial chromosome (BAC) clone contig map was constructed in an attempt to close the residual assembly gap existing therein. Twenty positional candidate genes including twelve C-repeat binding factor (CBF)/dehydration-responsive element binding factor 1 (DREB1) genes were identified from BAC-derived sequences and whole-genome shotgun sequences (WGS). CBF/DREB1 genes are organized in a tandem array within an approximately 296-Kb region. Eleven CBF/DREB1 genes were isolated and sequenced from F83005-5 and DZA045-5 which revealed high polymorphism among these accessions. Unique features characterizing CBF/DREB1 genes from M. truncatula, such as alternative splicing and large tandem duplication, are elucidated for the first time.
\end{abstract}

Conclusions: Overall, twenty genes were identified as potential candidates to explain Mt-FTQTL6 effect. Their future functional characterization will uncover the gene(s) involved in freezing tolerance difference observed between F83005-5 and DZA045-5. Knowledge transfer for breeding improvement of crop legumes is expected. Furthermore, CBF/DREB1 related data will certainly have a large impact on research studies targeting this group of transcriptional activators in M. truncatula and other legume species.

Keywords: Freezing tolerance, Medicago truncatula, Quantitative trait locus (QTL), Fine mapping, Candidate genes, CBF/DREB1 genes, Tandem duplication, Sequence polymorphism

\footnotetext{
* Correspondence: bruno.delbreil@univ-lille1.fr

'Université Lille 1, UMR 1281 Stress Abiotiques et Différenciation des

Végétaux cultivés (SADV), Bâtiment SN2, F-59655 Villeneuve d'Ascq Cedex,

France

Full list of author information is available at the end of the article
}

\section{Biomed Central}

(C) 2013 Tayeh et al.; licensee BioMed Central Ltd. This is an open access article distributed under the terms of the Creative Commons Attribution License (http://creativecommons.org/licenses/by/2.0), which permits unrestricted use, distribution, and reproduction in any medium, provided the original work is properly cited. 


\section{Background}

Freezing is an adverse abiotic factor with severe negative impacts on plant health and productivity [1]. Most temperate plants can increase their freezing tolerance after exposure to low temperatures, a process called cold acclimation [1-3]. CBF/DREB1 genes play a key role in the regulation of the transcriptome during cold acclimation [4]. They belong to the AP2/EREBP family of transcription factors and were first isolated from Arabidopsis thaliana (L.) Heynh. [5-7]. Up to now, CBF/DREB1 genes have been identified in numerous herbaceous and woody plant species [8-11] and different studies have reported their significant role in freezing tolerance [12-16].

Grain legumes are an important source of food and feed worldwide. With their seeds containing 20\% to $30 \%$ protein, they largely contribute to the protein requirements of humans and animals [17]. Forage legumes are a valuable source of protein, fiber and energy for livestock as well [17]. Besides their nutritional importance, legumes are an exceptional component to sustainable agriculture. In fact, most legume species are able to establish nitrogen-fixing symbioses with rhizobial bacteria $[17,18]$ which reduces the need for fertilizer application in crop rotation systems. Nowadays, the susceptibility to low temperatures and freezing conditions still represents a major constraint to the cultivation of legumes in many agro-ecological zones. The identification of the genes responsible for the natural freezing tolerance variation can enhance the breeding progress and subsequently the release of novel freezing-tolerant cultivars.

Medicago truncatula is an annual legume of Mediterranean origin [19]. It is not only a valuable forage crop as in Southern Australia [20] but has been chosen as a model molecular-genetic system for legume biology [21]. A large array of genomic tools has been developed for the reference accession A17 [22] and a draft sequence of the euchromatic portion of its genome comprising approximately $94 \%$ of all genes has been released [23]. These resources can accelerate the identification of the molecular determinants of various traits in $M$. truncatula including freezing tolerance. Knowledge can be then transferred to different agronomically and economically important crops considering their phylogenetic closeness to M. truncatula and the remarkable synteny between their genomes and that of M. truncatula [24-28].

Studies on cold acclimation and freezing tolerance in M. truncatula are scarce [29-34]. Few biochemical changes have been reported in response to low non-freezing temperatures for this species [30,31,34]. At the molecular level, transcripts corresponding to $M$. truncatula cold acclimation-specific gene 15 , a candidate $C B F / D R E B 1$ target, have been found to accumulate 6 hours after exposure to low temperature [32]. Four $C B F / D R E B 1$ genes, i.e. $M t C B F 1-4$, have been reported to be rapidly induced in response to cold stress [32,34,35]. Furthermore, the overexpression of $M t C B F 3$ (also named $M t D R E B 1 C$ ) has been shown to improve the freezing tolerance of transgenic $M$. truncatula accession Jemalong [14]. MtCBF1 and MtCBF4 are located on $M$. truncatula chromosomes 5 and 1 , respectively, but no information on the physical localization of $M t C B F 2-3$ has yet been obtained. Apart from $M t C B F 1-4$, no other $C B F / D R E B 1$ genes have been described and characterized from $M$. truncatula even though expressed sequence tag (EST) and complementary DNA (cDNA) potentially representing transcripts from other putative $C B F / D R E B 1$ genes are available [36,37].

Recently, Avia et al. [38] have uncovered natural variation for freezing tolerance among $15 \mathrm{M}$. truncatula accessions after a cold acclimation period. The genetic bases for freezing tolerance variation between the contrasted accessions F83005-5 and DZA045-5 have been identified using a quantitative trait locus (QTL) mapping approach [38]. A major freezing tolerance QTL (Mt-FTQTL6) accounting for $40 \%$ of the phenotypic variation has been mapped to a region of $M$. truncatula chromosome 6 [38] coinciding with an assembly gap in the A17 euchromatic sequence [39]. The present study aimed to fine map Mt-FTQTL6 and to identify genes located in the corresponding genomic region.

\section{Results}

\section{Freezing tolerance evaluation of recombinant lines validates Mt-FTQTL6 position and narrows down its confidence interval}

Eighteen $\mathrm{F}_{7}$ or $\mathrm{F}_{8}$ lines were evaluated for freezing tolerance after a cold acclimation period (Figure 1). Based on markers used in this study (Additional file 1), screened lines correspond to 9 different haplotypes; 7 of which carry recombination events within or next to Mt-FTQTL6 confidence interval (Figure 1). Phenotypic data from F83005-5 and DZA045-5, included as check plants, were significantly different as expected. Comparisons of the phenotypes and marker genotypes validated Mt-FTQTL6 confidence interval previously located between markers NT6001 and NT6019 [39]. Freezing damage scores from the self-pollinated progenies of lines 76-08-04 and 7606-187-02 showed that F83005-5 inserts upstream NT6001 have no phenotypic effect. The same conclusion was reached concerning F83005-5 inserts downstream NT6019 based on the progenies of line 76-05-06. Furthermore, Mt-FTQTL6 interval could be delineated to a smaller region of $0.4 \mathrm{cM}$ between markers MTIC153 and NT6054 (Figure 1 and 2; Additional file 2). A critical recombination event in line 76-02-86, as seen in lines 76-0286-07 and 76-02-86-12, suggested MTIC153 as the left marker for Mt-FTQTL6 confidence interval. The right marker, NT6054, was identified based on information from the progenies of lines 76-09-04 and 76-11-108-04. 


\begin{tabular}{|c|c|c|c|c|c|c|c|}
\hline \multicolumn{3}{|c|}{ Haplotype } & \begin{tabular}{|c|c|}
\multicolumn{2}{|c|}{ Genotype at Mt-FTQTL6 } \\
$\infty$
\end{tabular} & \multicolumn{3}{|c|}{ Freezing tolerance assessment } & \multirow[b]{2}{*}{$\begin{array}{l}\text { Freezing } \\
\text { tolerance } \\
\text { phenotype }\end{array}$} \\
\hline Group & $\begin{array}{l}\text { Mother } \\
\text { plant } \\
\text { identifier }\end{array}$ & $\begin{array}{c}\text { Generation } \\
\text { of the } \\
\text { progeny }\end{array}$ & 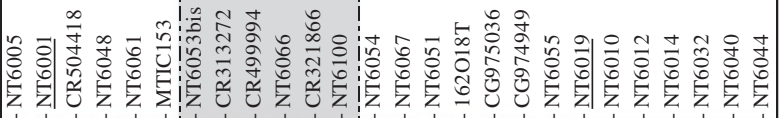 & $\begin{array}{l}\text { mean FDS } \\
\text { of F7/F8 line }\end{array}$ & $\begin{array}{l}\text { mean FDS } \\
\text { of F83005-5 }\end{array}$ & $\begin{array}{c}\text { mean FDS } \\
\text { of DZA045-5 }\end{array}$ & \\
\hline A & $\begin{array}{l}76-05-06 \\
76-05-04\end{array}$ & $\begin{array}{l}\text { F7 } \\
\text { F7 }\end{array}$ & 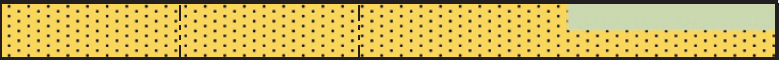 & $\begin{array}{l}3.3(\mathrm{~b}) \\
3.1(\mathrm{~b})\end{array}$ & 1.8 (a) & 3.4 (b) & $\begin{array}{l}\mathrm{S} \\
\mathrm{S}\end{array}$ \\
\hline B & $\begin{array}{r}76-08-04 \\
76-08-03 \\
\end{array}$ & $\begin{array}{l}\text { F7 } \\
\text { F7 }\end{array}$ & : & $\begin{array}{l}3.4(\mathrm{~b}) \\
3.4(\mathrm{~b})\end{array}$ & 1.9 (a) & 3.7 (b) & $\begin{array}{l}\mathrm{S} \\
\mathrm{S}\end{array}$ \\
\hline $\mathrm{C}$ & 76-09-04 & F7 & 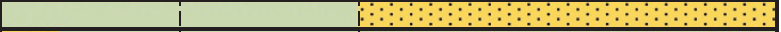 & $2.2(\mathrm{a})$ & 2.1(a) & $4.1(\mathrm{~b})$ & $\mathrm{T}$ \\
\hline $\mathrm{D}$ & $\begin{array}{l}76-11-105 \\
76-11-05 \\
\end{array}$ & $\begin{array}{l}\text { F7 } \\
\text { F7 }\end{array}$ & $\because \vdots \vdots \vdots$ & $\begin{array}{l}2.7(\mathrm{a}) \\
2.6(\mathrm{a}) \\
\end{array}$ & - & 4.1 (b) & $\begin{array}{l}\mathrm{T} \\
\mathrm{T}\end{array}$ \\
\hline $\mathrm{E}$ & $76-02-196-03$ & $\mathrm{~F} 8$ & 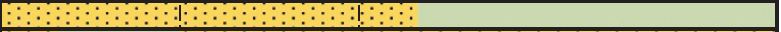 & $3.2(\mathrm{~b})$ & 2.5 (a) & $3.2(\mathrm{~b})$ & $\mathrm{S}$ \\
\hline $\mathrm{F}$ & $\begin{array}{l}76-02-86-07 \\
76-02-172-02\end{array}$ & $\begin{array}{l}\text { F8 } \\
\text { F8 }\end{array}$ & 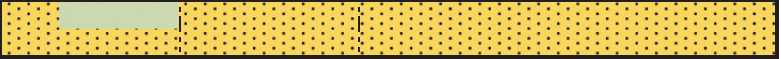 & $\begin{array}{l}3.5(b) \\
3.4(b)\end{array}$ & 2.3 (a) & 3.3 (b) & $\begin{array}{l}\mathrm{S} \\
\mathrm{S}\end{array}$ \\
\hline G & $\begin{array}{c}76-02-86-12 \\
76-02-276-03 \\
76-02-172-05 \\
\end{array}$ & $\begin{array}{l}\text { F8 } \\
\text { F8 } \\
\text { F8 }\end{array}$ & : & $\begin{array}{l}3.8 \text { (b) } \\
2.8(\mathrm{a}) \\
3.5(\mathrm{~b}) \\
\end{array}$ & 2.5 (a) & $3.6(b)$ & $\begin{array}{l}\mathrm{S} \\
\mathrm{T} \\
\mathrm{S}\end{array}$ \\
\hline $\mathrm{H}$ & $\begin{array}{r}76-06-187-02 \\
76-06-142-01 \\
\end{array}$ & $\begin{array}{l}\text { F8 } \\
\text { F8 }\end{array}$ & 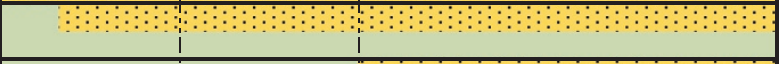 & $\begin{array}{l}3.3(\mathrm{~b}) \\
2.5(\mathrm{a}) \\
\end{array}$ & 2.5 (a) & $3.1(b)$ & $\begin{array}{l}\mathrm{S} \\
\mathrm{T}\end{array}$ \\
\hline I & $\begin{array}{c}76-11-108-04 \\
76-11-108-07 \\
76-11-51-08 \\
\end{array}$ & $\begin{array}{l}\text { F8 } \\
\text { F8 } \\
\text { F8 } \\
\end{array}$ & 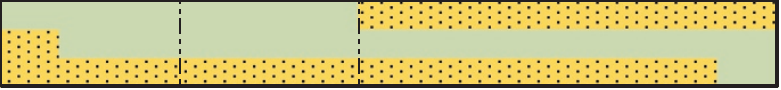 & $\begin{array}{l}3.1 \text { (a) } \\
2.9 \text { (a) } \\
3.6 \text { (b) } \\
\end{array}$ & - & - & $\begin{array}{l}\mathrm{T} \\
\mathrm{T} \\
\mathrm{S}\end{array}$ \\
\hline
\end{tabular}

Figure 1 Phenotypic evaluation of different haplotypes carrying or not recombination events within/next to the confidence interval of Mt-FTQTL6. $F_{7}$ and $F_{8}$ seedlings were obtained from the self-pollination of the homozygous $F_{6}$ and $F_{7}$ lines whose code names are indicated in the 'Mother plant identifier' column. These lines originally derive from a cross between M. truncatula accessions F83005-5 [freezing-tolerant] and DZA045-5 [freezing-sensitive] (see 'Development of plant material' in Methods). The genotypes of $\mathrm{F}_{7} / \mathrm{F}_{8}$ lines at Mt-FTQTL6 are provided based on information from 26 markers that are shown according to their established genetic and/or physical order ([39]; this study). Green bars refer to chromosomal regions harboring alleles from F83005-5. Orange dotted bars represent regions with alleles from DZA045-5. Markers bordering the confidence interval of Mt-FTQTL6 according to [39] are underlined. These are $5.7 \mathrm{CM}$ distant [39]. Haplotype groups A-I contain the recombinant and non-recombinant $F_{7} / F_{8}$ lines that were compared between each other. The mean freezing damage score (FDS) of each line is provided in the 'Freezing tolerance assessment' part of this figure. Pairwise comparisons of mean FDS were conducted between recombinant lines, respective controls (if any), F83005-5 and DZA045-5 (see 'Evaluation of freezing tolerance' in Methods). Letters (a) and (b) are used to distinguish significantly different FDS in each haplotype group. Due to the lack of individuals representing the parental accessions, the mean FDS of the progeny of recombinant line 76-11-108-04 in group I was only compared with those of the progenies of 76-11-108-07 and 76-11-51-08, considered as positive and negative controls respectively. Deduced phenotypes of $\mathrm{F}_{7} / \mathrm{F}_{8}$ lines are indicated to the right of the figure: ' $\mathrm{S}$ ', sensitive to freezing; 'T', tolerant to freezing. Grey-highlighted markers in the 'Genotype at Mt-FTQTL6' part are those contained in Mt-FTQTL6's confidence interval delimited according to genotype and phenotype data from screened lines.

\section{Full-BAC sequencing and WGS assembly provide sequences spanning the assembly gap coinciding with Mt-FTQTL6}

Efforts have been made to close the assembly gap between markers NT6001 and NT6019. Six primary BAC clone contigs partly spanning Mt-FTQTL6 could thus be constructed (Additional files 3, 4, 5). Mt-FTQTL6 confidence interval delimited through fine mapping (see above) is partly covered by BAC clone contig IV (Additional file 5). In order to generate the candidate genomic sequence of

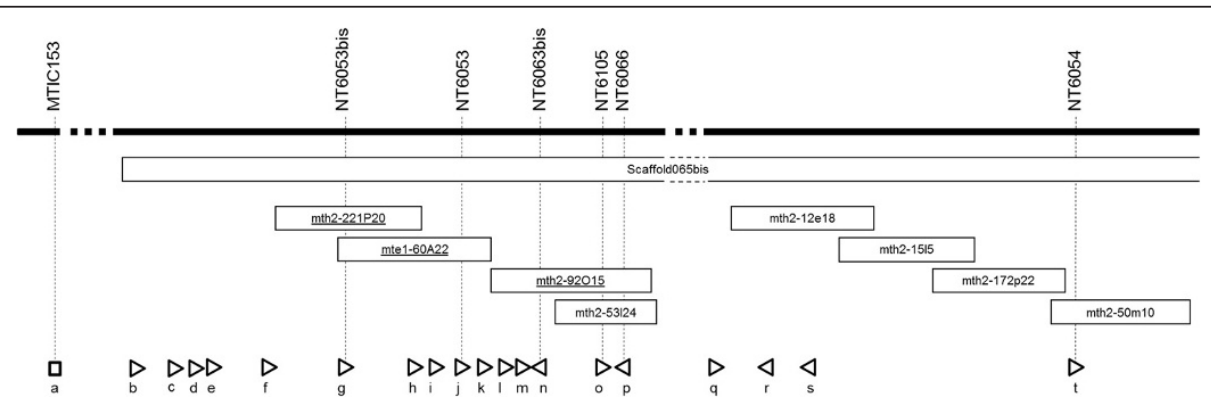

Figure 2 Genetic and physical map positions of Mt-FTQTL6 candidate genes on $\boldsymbol{M}$. truncatula chromosome $\mathbf{6}$. Genetic markers shown at the top of the figure refer to gene-based markers bordering or located in the confidence interval of Mt-FTQTL6 (refer to Figure 1 and Additional file 2). BAC clones originating from the genomic region corresponding to Mt-FTQTL6 are presented according to their relative positions and with respect to genetic markers (see Additional file 5 for details on the BAC clone contig map). The identifiers of the BAC clones whose inserts were sequenced in this study are underlined. Scaffold065bis is a WGS scaffold from A17 that largely covers the confidence interval of Mt-FTQTL6. Arrowheads indicate the position and the transcriptional orientation of candidate genes. No information on the transcriptional orientation of MtBAG-1 is available. a, MtBAG-1; b, MtCBF14; C, MtCBF13; d, MtCBF3; e, MtCBF12; f, MtCBF11; g, MtCBF2; h, MtCBF10; i, MtCBF9; j, MtCBF8; k, MtCBF7; I, MtCBF6; m, MtCBF5; n, MtPERLD; o, MTR_050s0019; p, MTR_050s0020; q, MtZFWD; r, MTR_05450001; s, MTR_05450019; t, MTR_69089580. 
Mt-FTQTL6, inserts from BAC clones mth2-92O15, mte160A22 and mth2-221P20, were first fully-sequenced (GenBank accession numbers [GB acc] KF006382-84). Sequence information from these 3 clones (Figure 2) extended BAC clone mth2-53l24 insert sequence (GB acc AC229695) with 217,951 bp assembled in 17 contigs (Additional file 6). With Illumina WGS sequences becoming available from A17 (F. Debellé, personal communication), BAC by BAC sequencing has not been kept up. Instead, marker and BACend sequences associated with Mt-FTQTL6 were used to search for scaffold sequences corresponding to the target region. A scaffold of more than $1 \mathrm{Mb}$ long, namely scaffold065bis, was thus identified. It covers BAC clone contigs IV and V (Additional file 5) and extends mth2-221P20 insert sequence with approximately $155 \mathrm{~Kb}$ (Figure 2).

\section{Twenty non-transposon genes reside in Mt-FTQTL6 confidence interval}

Twenty non-transposon genes with significant matches to GenBank's non-redundant nucleotide ( $\mathrm{nr} / \mathrm{nt}$ ), expressed sequence tag and protein databases, including those corresponding to markers MTIC153 and NT6054, could be identified in the candidate sequence for Mt-FTQTL6 (Figure 2; Table 1). Spacing between adjacent genes varies from 1,586 bp (between MtCBF5 and MtPERLD) up to 318,549 bp (between MTR_054s0019 and MTR_6g089580). Coding sequences have an overall $\mathrm{G}+\mathrm{C}$ content of $42.15 \%$. Sixteen genes are supported by cognate EST and additionally 7 of them by cDNA sequences (Table 1). Comparisons between genomic and EST/CDNA sequences indicate that four genes (i.e. $M t C B F 8, M t C B F 6, M t P E R L D$ and MTR_054s0019) have 2 transcript isoforms each.

All positional candidate genes for Mt-FTQTL6 were found to have highly similar counterparts across a set of dicotyledonous species for which genome sequence information is available (Additional file 7). All, except for homologous genes to MTR_054s0001, are contained in syntenic blocks exhibiting large gene order conservation with Mt-FTQTL6 (Additional file 7). Three chromosomal segments in A. thaliana and in Solanum lycopersicum L., two segments in Populus trichocarpa (Torr. \& Gray) and a single segment in Vitis vinifera L. share colinearity with Mt-FTQTL6. Among legumes, two additional M. truncatula, six Glycine $\max$ (L.) Merr. and three Lotus japonicus L. regions are colinear with Mt-FTQTL6. Few rearrangements could be noted among conserved regions including gene loss, local duplication or also translocation events (Additional file 7).

Twelve candidate genes organized in a tandem array belong to the CBF/DREB1 group of the AP2/EREBP transcription factor family

$C B F / D R E B 1$ genes represent $60 \%$ of all candidates for MtFTQTL6 (Table 1). They are organized in a tandem cluster spanning a region of approximately $296 \mathrm{~Kb}$ (Figure 2). No intervening spacer genes, except those for retrotransposons, exist in between. MtCBF12 and MtCBF13 are pseudogenes. A deletion of a guanine at position 314 in MtCBF12 coding sequence causes a frameshift and a premature stop codon at the $148^{\text {th }}$ amino acid. MtCBF13 coding region shows an in-frame 848-bp insertion and two point mutations leading each to a premature stop codon. MtCBF2-3;5-11;14 are likely to represent functional protein-coding genes. The corresponding proteins share 61 to $92 \%$ overall amino acid identity (Additional file 8) and all show typical features of the CBF/DREB1 group (Figure 3). They have each a 58-amino acid long AP2/ERF nuclear signaling and DNA binding domain [42-44] and an acidic C-terminal region [isoelectric point ( $\mathrm{pI}$ ) ranging between 3.94 and 5.04] that may function in transactivation [45]. MtCBF11 contains in addition to the 58-amino acid AP2/ERF domain, a 17-amino acid long sequence most likely corresponding to the $\mathrm{C}$-terminal end of a second AP2/ERF domain (Figures 3 and 4). CBF signature sequences comprising PKKP/RAGRxKFxETRHP and DSAWR motifs bracketing the AP2/ERF domain [8] are largely conserved among MtCBF2-3;5-11;14. These latter also show $\mathrm{A}(\mathrm{A} / \mathrm{V}) \mathrm{xxA}(\mathrm{A} / \mathrm{V}) \mathrm{xxF}$ [46] and LWSY motifs [47], reported to be conserved in CBF/DREB1 proteins in different plant species. Variants at the CBF/DREB1 characteristic amino acid sequences are listed in Additional file 9. The $(\mathrm{L} / \mathrm{Y})(\mathrm{L} / \mathrm{Y}) \mathrm{x}(\mathrm{N} / \mathrm{S})(\mathrm{M} / \mathrm{L}) \mathrm{A}(\mathrm{E} / \mathrm{Q}) \mathrm{G}(\mathrm{M} / \mathrm{L})(\mathrm{L} / \mathrm{M}) \mathrm{xxPP}$ sequence, previously suggested as a CBF/DREB1 conserved motif [46] is not present in MtCBF2-3;5-14 except for the NMA motif. These proteins have rather a $\mathrm{NM}(\mathrm{A} / \mathrm{V})$ LMSPTHS conserved sequence at the same position.

\section{Distinct levels of polymorphism exist between MtCBF2-3;5-12;14 alleles from F83005-5 and DZA045-5}

$M t C B F 2-3 ; 5-12 ; 14$ specific primers yielded positive amplification from F83005-5 and DZA045-5 indicating that all 11 genes are present in these accessions. No amplification could be obtained with $M t C B F 13$-specific primers from both accessions despite using different primer combinations and PCR conditions. For $M t C B F 2$, two distinct PCR products were obtained from F83005-5 (named MtCBF2a and MtCBF2b) using distinct forward primers but not from DZA045-5, thus indicating that this gene has undergone duplication at least in F83005-5's background. Overall, 14,953 bp (F83005-5) and 15,038 bp (DZA045-5) of comparable sequences were generated (Additional file 10). They show a total of 402 single nucleotide polymorphism (SNP), 41 insertion-deletion (indel) and 9 simple sequence repeat (SSR) polymorphisms with 206 SNP, 8 indel and 3 SSR located in the coding sequences (Additional file 10). Contrary to A17 and F83005-5, DZA045-5 has an insertion of a 160-bp short interspersed nuclear element (SINE) in the coding 
Table 1 Positional candidate genes for Mt-FTQTL6

\begin{tabular}{|c|c|c|c|c|c|c|c|c|c|}
\hline $\begin{array}{l}\text { Gene ID } \\
\text { [reference] }\end{array}$ & $\begin{array}{l}\text { BAC clone } \\
\text { and/or WGS } \\
\text { sequence }\end{array}$ & EST (1) & cDNA (1) & $\begin{array}{l}\text { Number } \\
\text { of } \\
\text { splicing } \\
\text { isoforms }\end{array}$ & $\begin{array}{l}\text { Number of intron } \\
\text { (s) in the coding } \\
\text { sequence [intron } \\
\text { size(s) in bp] }\end{array}$ & $\begin{array}{l}\text { Putative gene } \\
\text { product }\end{array}$ & $\begin{array}{c}\text { Amino acid } \\
\text { length [length } \\
\text { of the acidic C-terminal } \\
\text { domain] (2) }\end{array}$ & $\begin{array}{c}\text { Theoretical } \\
\text { molecular } \\
\text { weight } \\
\text { (KDa) }\end{array}$ & $\begin{array}{l}\text { Theoretical } \\
\mathrm{pl} \text { [pl of the } \\
\text { C-terminal } \\
\text { domain] (2) }\end{array}$ \\
\hline MtBAG-1 [40] & - & $\begin{array}{l}\text { AW299190; BG646253; AW257319; } \\
\text { AW256371; BI308136; AL369679; } \\
\text { AW329645; AL373067; BF006595; } \\
\text { AW694037; BF650244; AL373068; } \\
\text { CA919955; AL373067; CA917144; } \\
\text { BE325495; EX533119; BG588510; } \\
\text { BE322176 }\end{array}$ & - & 1 & - & $\begin{array}{l}\text { Bcl-2-associated } \\
\text { athanogene }\end{array}$ & 355 & 39.9 & 9.37 \\
\hline MtCBF14 & Scaffold065bis & - & - & - & - & $\begin{array}{l}\text { CBF/DREB1 } \\
\text { protein }\end{array}$ & 230 [103] & 25.74 & $5.55[4.02]$ \\
\hline MtCBF13 & Scaffold065bis & - & - & - & - & $\begin{array}{l}\text { CBF/DREB1 } \\
\text { protein }\end{array}$ & - & - & - \\
\hline $\begin{array}{l}\text { MtCBF3 [32]/ } \\
\text { MtDREB1C [14] }\end{array}$ & Scaffold065bis & $\begin{array}{l}\text { CA920049; CF069650; BG581707; } \\
\text { BF005835; BQ138271; BG582534 }\end{array}$ & $\begin{array}{l}\text { DQ267620; } \\
\text { EU139868 }\end{array}$ & 1 & - & $\begin{array}{l}\text { CBF/DREB1 } \\
\text { protein }\end{array}$ & 227 [109] & 25.99 & $5.64[4.11]$ \\
\hline MtCBF12 & Scaffold065bis & GT136747; GT141343 & BT134401 & 1 & - & $\begin{array}{l}\text { CBF/DREB1 } \\
\text { protein }\end{array}$ & - & - & - \\
\hline MtCBF11 & Scaffold065bis & - & - & - & - & $\begin{array}{l}\text { CBF/DREB1 } \\
\text { protein }\end{array}$ & 281 [103] & 31.21 & $5.66[4.07]$ \\
\hline MtCBF2 [32] & $\begin{array}{l}\text { Scaffold065bis; } \\
\text { mth2-221P20; } \\
\text { mte1-60A22 }\end{array}$ & BF520341 & EU139867 & 1 & - & $\begin{array}{l}\text { CBF/DREB1 } \\
\text { protein }\end{array}$ & $230[106]$ & 26.07 & $5.8[4.12]$ \\
\hline MtCBF10 & $\begin{array}{l}\text { Scaffold065bis; } \\
\text { mth2-221P20; } \\
\text { mte1-60A22 }\end{array}$ & - & - & - & - & $\begin{array}{l}\text { CBF/DREB1 } \\
\text { protein }\end{array}$ & 198 [104] & 22.58 & $5.39[4.03]$ \\
\hline MtCBF9 & $\begin{array}{l}\text { Scaffold065bis; } \\
\text { mte1-60A22 }\end{array}$ & CX528143 & - & 1 & - & $\begin{array}{l}\text { CBF/DREB1 } \\
\text { protein }\end{array}$ & 208 [114] & 24.04 & $4.99[3.94]$ \\
\hline MtCBF8 (a) & $\begin{array}{l}\text { Scaffold065bis; } \\
\text { mte1-60A22 }\end{array}$ & $\begin{array}{c}\text { EY477920; BQ165478; CA921976; BF005540; } \\
\text { AW573630; BQ165479; EY476564; } \\
\text { BE999274; BE998545;BE999273; CB893700 }\end{array}$ & $\begin{array}{l}\text { DQ778006; } \\
\text { BT146058 }\end{array}$ & 2 & $\begin{array}{c}\text { no intron/1 intron } \\
{[316]}\end{array}$ & $\begin{array}{l}\text { CBF/DREB1 } \\
\text { protein }\end{array}$ & 215 [100]/271 [156] & $24.87 / 31.11$ & $\begin{array}{l}6.1[4.27] / \\
8.37[4.92]\end{array}$ \\
\hline MtCBF7 & $\begin{array}{l}\text { Scaffold065bis; } \\
\text { mte1-60A22 }\end{array}$ & BF005905 & - & 1 & 1 intron [279] & $\begin{array}{l}\text { CBF/DREB1 } \\
\text { protein }\end{array}$ & 245 [130] & 27.88 & $6.66[4.60]$ \\
\hline MtCBF6 & $\begin{array}{l}\text { Scaffold065bis; } \\
\text { mth2-92015 }\end{array}$ & CF069139; AW775188; BF006671;CA919708 & - & 2 & $\begin{array}{c}\text { no intron/1 intron } \\
{[352]}\end{array}$ & $\begin{array}{l}\text { CBF/DREB1 } \\
\text { protein }\end{array}$ & $216[101] / 248[133]$ & $24.67 / 28.23$ & $\begin{array}{l}6.31[4.22] / \\
8.41[4.84]\end{array}$ \\
\hline MtCBF5 & $\begin{array}{l}\text { Scaffold065bis; } \\
\text { mth2-92015 }\end{array}$ & BG648933; BF005756; CA920720 & - & 1 & 1 intron [380] & $\begin{array}{l}\text { CBF/DREB1 } \\
\text { protein }\end{array}$ & $267[152]$ & 30.54 & $8.87[5.04]$ \\
\hline
\end{tabular}


Table 1 Positional candidate genes for Mt-FTQTL6 (Continued)

\begin{tabular}{|c|c|c|c|c|c|c|c|c|c|}
\hline MtPERLD & $\begin{array}{l}\text { Scaffold065bis; } \\
\text { mth2-92015 }\end{array}$ & $\begin{array}{c}\text { BF631847; EV255869; AL373022; CB892925; } \\
\text { EY476043; BG449960; BG648146; BF639371; } \\
\text { BG648635; CX527766; CX527793; } \\
\text { CX527254; BI267056; BF521243; BF642637; } \\
\text { CX523947; BE319009; AL373021; BF635170; } \\
\text { BM779066; BQ152673; AW736243; } \\
\text { BG646840 }\end{array}$ & $\begin{array}{l}\text { BT051744; } \\
\text { BT139597 }\end{array}$ & 2 & $\begin{array}{c}4 \text { introns } \\
\text { [2807;93;1008;2220]/ } \\
5 \text { introns }[123 ; 2663 ; \\
93 ; 1008 ; 2220]\end{array}$ & $\begin{array}{l}\text { Per1-like family } \\
\text { protein }\end{array}$ & 342 & 39.48 & 7.6 \\
\hline $\begin{array}{c}\text { MTR_050s0020 } \\
\text { [23] }\end{array}$ & $\begin{array}{l}\text { Scaffold065bis; } \\
\text { mth2-92015; } \\
\text { mth2-53124 } \\
\text { (GB acc } \\
\text { AC229695) (b) }\end{array}$ & BF635955; GT141039; GT136423 & - & 1 & $\begin{array}{c}15 \text { introns [2336; } \\
137 ; 162 ; 266 ; 470 ; \\
89 ; 86 ; 126 ; 80 ; 626 ; \\
88 ; 84 ; 86 ; 80 ; 450] \\
\text { (c) }\end{array}$ & $\begin{array}{l}\text { ABC transporter } \\
\text { B family } \\
\text { member }\end{array}$ & 715 & 78.37 & 9.07 \\
\hline $\begin{array}{c}\text { MTR_050s0019 } \\
{[23]}\end{array}$ & $\begin{array}{c}\text { Scaffold065bis; } \\
\text { mth2-92015; } \\
\text { mth2-53124 } \\
\text { (GB acc } \\
\text { AC229695) }\end{array}$ & EV258193; CX522284 & BT147320 & 1 & 1 intron [721] & $\begin{array}{c}\text { Conserved } \\
\text { uncharacterized } \\
\text { protein }\end{array}$ & 242 & 26.45 & 8.56 \\
\hline MtZFWD & Scaffold065bis & CX520203; BE239869 & - & 1 & $\begin{array}{c}8 \text { introns }[939 ; 162 ; \\
143 ; 306 ; 104 ; 78 ; \\
598 ; 759] \text { (d) }\end{array}$ & $\begin{array}{l}\text { Zinc finger } \\
\text { CCCH and } \\
\text { WD40 domain- } \\
\text { containing } \\
\text { protein }\end{array}$ & 438 & 47.29 & 7.85 \\
\hline $\begin{array}{c}\text { MTR_054s0001 } \\
{[23]}\end{array}$ & $\begin{array}{l}\text { Scaffold065bis; } \\
\text { mth2-12e18 } \\
\text { (GB acc } \\
\text { AC229727) }\end{array}$ & BQ138417 & - & 1 & $\begin{array}{c}11 \text { introns }[1352 ; \\
982 ; 1537 ; 116 ; 110 \\
>418 ; 443 ; 1495 ; 27 \\
139 ; 627] \text { (e) }\end{array}$ & $\begin{array}{l}\text { DNA 3'- } \\
\text { phosphoesterase }\end{array}$ & 338 & 37.66 & 6.56 \\
\hline $\begin{array}{c}\text { MTR_054s0019 } \\
\text { [23] }\end{array}$ & $\begin{array}{l}\text { Scaffold065bis; } \\
\text { mth2-12e18 } \\
\text { (GB acc } \\
\text { AC229727) }\end{array}$ & $\begin{array}{c}\text { CB894631; CF068286; DW018377; } \\
\text { BG647692; BE316675; EV256045; BF639952; } \\
\text { CB893865; EV261994; BE322046; BI263625; } \\
\text { AW691341; CX535182; BI265523; BE998615; } \\
\text { CA918979; BI266410; CA858657; BF520558; } \\
\text { BF637666; BI267231; AJ503890 }\end{array}$ & $\begin{array}{l}\text { BT051762; } \\
\text { BT148189; } \\
\text { BT136112 }\end{array}$ & 2 & $\begin{array}{l}5 \text { introns [938; 202; } \\
1366 ; 511 ; 864] / \\
\text { different translation } \\
\text { start site and novel } \\
\text { intron of } 4532 \mathrm{bp}\end{array}$ & $\begin{array}{c}\text { Sorbitol } \\
\text { dehydrogenase- } \\
\text { like protein }\end{array}$ & 362 & 39 & 6.13 \\
\hline $\begin{array}{c}\text { MTR_69089580 } \\
{[23]}\end{array}$ & $\begin{array}{l}\text { Scaffold065bis; } \\
\text { mth2-50m10 } \\
\text { (GB acc } \\
\text { AC174372) }\end{array}$ & $\begin{array}{l}\text { BG648131; AW685633; AW586532; } \\
\text { Al974700; CA920607 }\end{array}$ & - & 1 & no intron & $\begin{array}{l}\text { unknown } \\
\text { protein }\end{array}$ & 628 & 71.8 & 8.38 \\
\hline \multicolumn{10}{|c|}{ 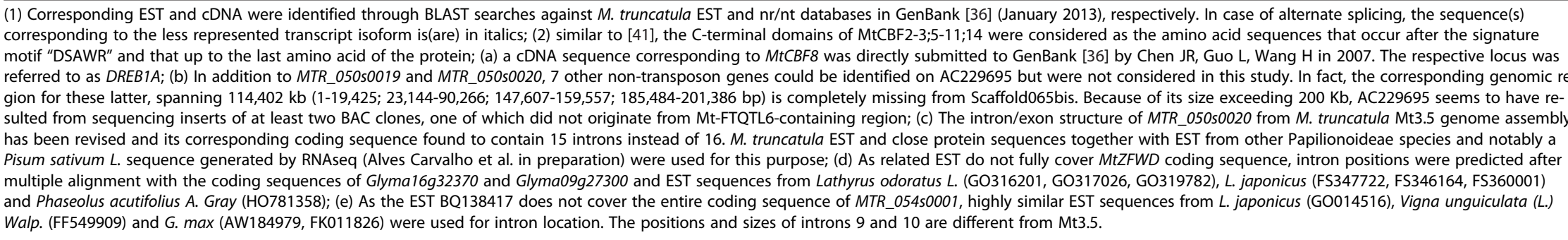 } \\
\hline
\end{tabular}




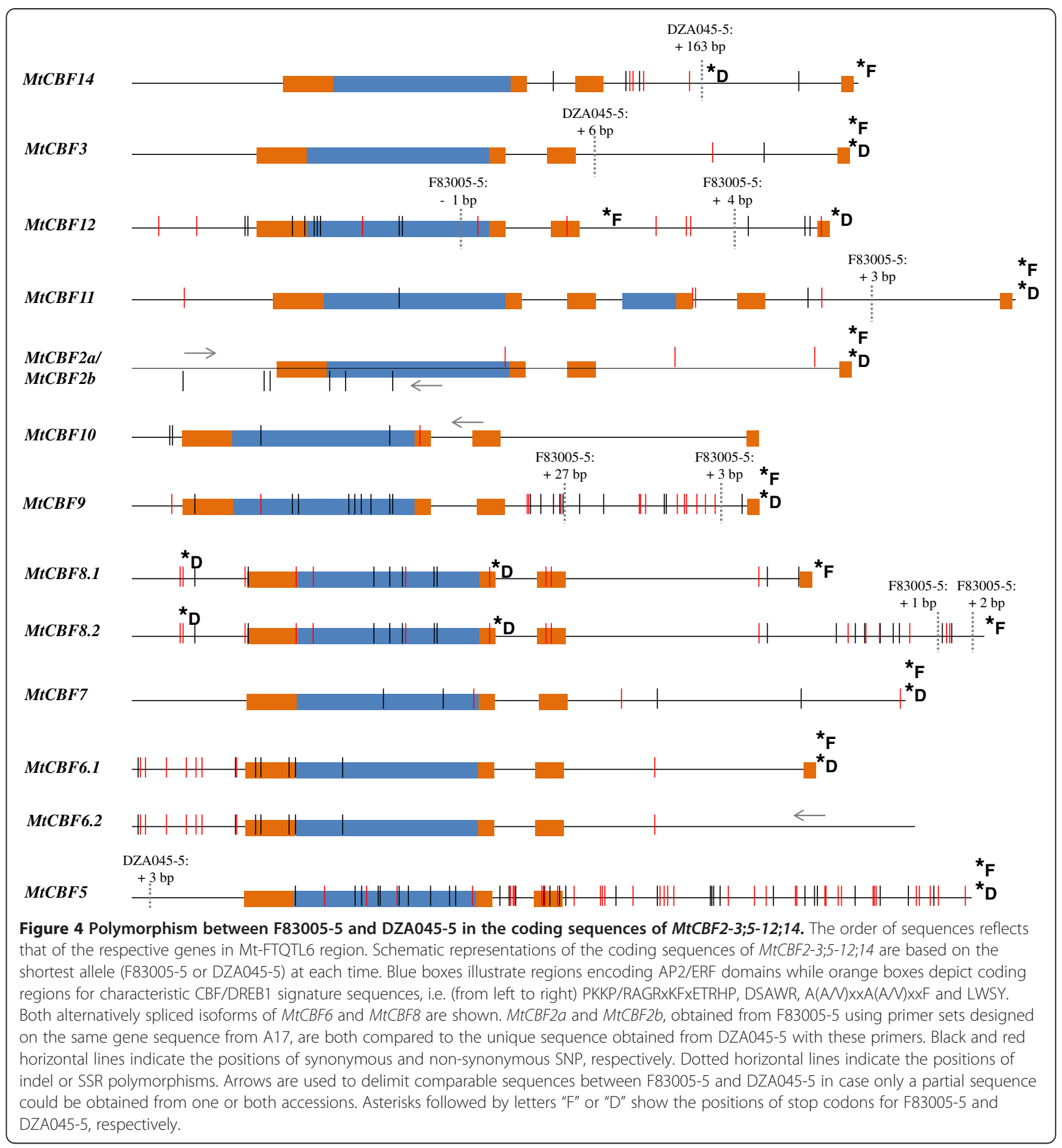

sequence of MtCBF14 and another SINE element in the $5^{\prime}$ upstream region of $M t C B F 8$. F83005-5 has a specific insertion of a putative miniature inverted-repeat transposable element in the $5^{\prime}$ upstream region of $M t C B F 6$.

Figure 4 illustrates allelic variation between F83005-5 and DZA045-5 in the coding regions of MtCBF2-3; 5-12;14. As it could be noticed, nucleotide changes leading to differences at the amino acid level are not evenly distributed amongst genes. Amino acid substitution difference between F83005-5 and DZA045-5 ranges between 1 (MtCBF3) and 34 (MtCBF5). MtCBF14 and $M t C B F 8$ are likely to encode truncated proteins in freezing-sensitive accession DZA045-5 but not in freezing-tolerant accessions F83005-5 and A17. In contrast, $M t C B F 12$ is likely to encode a full-length protein in DZA045-5 which is not the case for F83005-5 and A17. 


\section{Discussion}

M. truncatula is a valuable forage crop and also a prominent model for legume genomics. Freezing tolerance QTL have been previously identified in $M$. truncatula [38]. In the current study, Mt-FTQTL6 has been finely mapped by genetically and physiologically characterizing recombinant haplotypes carrying recombination events within the QTL confidence interval. Genomic data have been developed to fill the genome assembly gap in Mt-FTQTL6 region and have permitted to reveal twenty positional candidate genes. Interestingly, twelve genes belong to the CBF/DREB1 group of the AP2/EREBP transcription factor family and occur in tandem array.

\section{Current knowledge on the functions of the twenty positional candidate genes for Mt-FTQTL6}

The fine mapping step has significantly reduced MtFTQTL6's confidence interval and has subsequently allowed the identification of 20 candidate genes. Functional data regarding these candidate genes are still limited at present (Additional file 11). Only homologs/orthologs of MtCBF2-3;5-14, MtBAG-1, MTR_054s0019 and MtZDP have been studied in plant species [13,15,35,51-54]. For MtPERLD and MTR_050s0020 which are members of evolutionary conserved gene families, only non-plant homologs have been described [55-57]. MtZFWD contains both a $\mathrm{CCCH}$ zinc finger domain and WD40 repeats and thus belongs to a plant-specific subgroup of $\mathrm{CCCH}$ zinc finger protein family [58] that is not yet functionally described. No data are available for MTR_050s0019 and MTR_6g089580 to infer putative functions. Out of all candidate genes (Table 1), only $M t C B F 2$ and $M t C B F 3$ have been functionally characterized in M. truncatula. MtCBF2 and $M t C B F 3$ were reported to display both a rapid and transient accumulation of transcripts in the leaves of 3-week old $M$. truncatula plants after exposure to low temperature treatment [32,34]. Furthermore, transgenic $M$. truncatula lines overexpressing $M t C B F 3$ were shown to exhibit an improved freezing tolerance compared to the wild-type [14]. However, even if the CBF/DREB1 genes can be considered as the most likely candidates for the Mt-FTQTL6 effect, none of the non-functionally characterized genes can be excluded at present. Further knowledge needs to be gained regarding the different candidate genes and the QTL of interest itself.

\section{Co-location between a freezing tolerance QTL and $C B F / D R E B 1$ genes in a legume species}

$C B F / D R E B 1$ genes were found to co-locate with QTL for freezing tolerance in several plant species including A. thaliana [59,60], Triticum monococcum L. [61], Triticum aestivum L. [62] and Hordeum vulgare L. subsp. vulgare [63]. A large deletion in the promoter region of A. thaliana CBF2 [59] and co-locations of freezing tolerance QTL in
T. monococcum [61] and H. vulgare subsp. vulgare [63] with QTL for expression of cold-induced CBF/DREB1 target gene COR14b and accumulation of COR14b protein suggested $C B F / D R E B 1$ genes being responsible for the QTL effects. The identification of $C B F / D R E B 1$ genes among positional candidates of Mt-FTQTL6 provides an additional example of a co-location between a freezing tolerance QTL and this group of genes but for the first time in a legume species. It will be of great interest to inspect such colocation in other legumes especially $P$. sativum having a freezing damage QTL syntenic to Mt-FTQTL6 [39].

\section{Large size of the CBF/DREB1 group in M. truncatula}

This study has permitted the physical positioning of twelve M. truncatula CBF/DREB1 genes through the assembly of Mt-FTQTL6 region. Apart from $M t C B F 2$ and $M t C B F 3$ that were identified by Pennycooke et al. [32] and DREB1A whose cDNA sequence was directly submitted to GenBank (GB acc DQ778006), the other $C B F /$ $D R E B 1$ genes associated with Mt-FTQTL6 were not previously annotated or described (Table 1). As the name "MtCBF4" has been recently assigned to a CBF/DREB1 gene located on $M$. truncatula chromosome 1 [35], the novel genes including DREB1A were here given consecutive numbers from 5 to 14 starting from the most proximal to MtPERLD (Figure 2).

$M t C B F 2-3 ; 5-14$ occur in tandem array and are in direct orientation (Figure 2) which suggests that they are most likely derived from an unequal crossing over mechanism $[64,65]$. However, the contribution of transposable elements to this duplication event cannot be totally excluded [65], especially with several transposon and retrotransposon insertions being evident between $C B F / D R E B 1$ genes (data not shown).

According to Young et al. [23], M. truncatula has experienced high rates of local gene duplication compared to other plant genomes. It may thus not be surprising to have such a large tandem array organization for the $M t C B F 2-3 ; 5-14$ locus. Similar tandem duplications have been described for nucleotide-binding site-leucine-rich repeat genes [66] and lipoxygenase genes [67] on $M$. truncatula chromosomes 6 and 8, respectively. However, the main particularity of the tandem cluster in Mt-FTQTL6 region is that it concerns $C B F / D R E B 1$ genes. Large groups of $C B F / D R E B 1$ genes have always been thought to be limited to monocotyledons. This study reports for the first time that the CBF/DREB1 genes can also be highly duplicated in legume species. $M$. truncatula has at least 17 $C B F / D R E B 1$ genes (considering $M t C B F 2 a$ and $M t C B F 2 b$ from F83005-5) all located in homoeologous regions (Additional file 7). A recent report has similarly shown that Eucalyptus grandis genome contains 17 CBF/DREB1 genes [68]. It will be next important to determine if other legumes have as many genes that belong to the $\mathrm{CBF} /$ 
DREB1 group as M. truncatula. First evidences denote that there may not be a general trend at this level. As shown in Additional file 7, G. max does not have any duplication of $C B F / D R E B 1$ genes in Mt-FTQTL6 syntenic regions. In contrast, L. japonicus has 7 tandemly-arrayed putative $C B F / D R E B 1$ genes on chromosome 4 .

\section{Complexity of the CBF/DREB1 locus on M. truncatula chromosome 6}

As for other duplication modes, tandem duplication generates identical genes that evolve in different ways [65,69-75]. In the case of the locus harboring MtCBF2$3 ; 5-14$, some evidences of pseudogenization are apparent: premature stop codons leading to truncated proteins exist within the corresponding coding sequences of $M t C B F 13$ and $M t C B F 12$ in A17, MtCBF12 in F83005-5 and MtCBF8 and $M t C B F 14$ in DZA045-5 (Figure 4). However, most $C B F / D R E B 1$ duplicates are likely to encode functional proteins. Up to date, information regarding the expression profiles of $M t C B F 2-3 ; 5-14$ is still greatly lacking. M. truncatula gene expression atlas [76] provides only a first glimpse on the expression of some genes among MtCBF2-3;5-14 under unstressed conditions (Additional file 12). It is thus crucial to conduct a complete survey on the expression patterns (including under cold stress) of all $C B F / D R E B 1$ genes on M. truncatula chromosome 6. This will determine whether tandemly duplicated $C B F /$ $D R E B 1$ genes have evolved or not different expression patterns and so possibly distinct functions as already reported for different $C B F / D R E B 1$ genes in other plant species $[10,41,77,78]$. The characterization of $M t C B F 11$ deserves a particular attention as its predicted protein product contains a full-length and an additional 17-amino acid long partial AP2/ERF domain (Figure 3 and 4). MtCBF11 has most likely arisen from an inframe fusion of the $5^{\prime}$ portion of the coding region from a first $C B F / D R E B 1$ gene with the 3 ' portion of the coding sequence from a second gene.

Alternative splicing events can diverge between duplicates, including organ- and stress-specific differences, and result in functional variation [79]. Based on genomic sequence alignment with EST and cDNA data, $M t C B F 6$ and $M t C B F 8$ have two transcript variants each, generated by intron retention/splicing events (Table 1). $M t C B F 5$ and $M t C B F 7$ contain each an intron at the same position as for MtCBF6 and $M t C B F 8$ intronspliced isoforms but no evidence yet suggests that $M t C B F 5$ and MtCBF7 may have intron-retaining transcript forms similar to MtCBF6 and MtCBF8. As EST databases can be incomplete with regard to alternative splicing transcript variants, reverse transcription PCR or transcription analysis using second generation sequencing would allow determining alternative splicing patterns with more precision. This is the first study to provide data on the presence of introns and alternative splicing forms in $C B F / D R E B 1$ genes. Each of the isoforms of $M t C B F 5-8$ will need to be characterized apart in order to determine if these are functional and then compare them to other $C B F / D R E B 1$ genes and alternatively spliced forms if any. Any possible association of alternative splicing of $C B F /$ $D R E B 1$ genes with $M$. truncatula response to low temperatures should be inspected. Recent reports from grasses have shown the existence of alternatively spliced isoforms for AP2/EREBP family members [80-82] homologous to A. thaliana DREB2 [6] which is known to be activated by dehydration and high-salt stresses. The alternative splicing of these genes was suggested to be important for reducing the activity of their target genes under unstressed conditions and thus preventing negative effects on plant growth.

\section{Conclusions}

The present study has permitted to narrow down the confidence interval of a major freezing tolerance QTL on M. truncatula chromosome 6 and to identify genes located therein. No similar studies related to legume freezing tolerance have to date been reported. Candidate genes represent important elements toward positional cloning of Mt-FTQTL6. Information gained from M. truncatula being a model species should be transferred to agronomically and economically important crop legumes. The BAC clone contig map constructed for the assembly gap coinciding with Mt-FTQTL6 will be interesting in efforts to clone important loci mapped to the same region as MtFTQTL6 including a locus for resistance to Subterranean clover mottle virus [83] and a QTL for the number of secondary branches [84]. When sequenced from F83005-5 and DZA045-5, MtCBF2-3;5-12;14 coding sequences showed distinct levels of indels and non-synonymous mutations which suggest that they have evolved in a heterogenous manner. Allelic variation identified on coding and immediate flanking sequences of $M t C B F 2-3 ; 5-$ $12 ; 14$ will be useful for future studies to establish the adaptative value of the different $C B F / D R E B 1$ duplicates.

\section{Methods}

\section{Development of plant material}

M. truncatula LR3 population comprises $178 \mathrm{~F}_{2: 5}$ recombinant inbred lines (RIL) obtained by single seed descent from a cross between the freezing-tolerant accession F83005-5 and the freezing-sensitive accession DZA045-5 [85]. F83005-5 derives from a natural population collected in France and DZA045-5 from an Algerian population [86]. Genotypic data from the LR3 population [38] indicate that twelve RIL (RIL4, 13, 17, 22, 76, 90, 101, 151, 161, 165 and 241) have residual heterozygosity at MtFTQTL6 peak marker, MTIC153. Among them, RIL76 is particularly important because: (1) it is homozygous at the 
confidence intervals of both other freezing tolerance QTL from the LR3 population mapped on chromosomes 1 and 4 [38]; (2) it carries the sensitive parent's alleles at both these QTL; and (3) it shows a low overall genome heterozygosity. RIL76 sister lines were therefore chosen for the development of inbred lines showing recombination events at Mt-FTQTL6. Twelve $F_{5}$ lines were grown and submitted to a genotypic analysis using: SSR markers evenly spaced on the eight $M$. truncatula chromosomes (3 to 6 markers per chromosome; 33 markers in total), the nearest SSR marker to the peak of each of the freezing tolerance QTL on chromosomes 1 and 4, and SNP and SSR/ indel markers closely linked to Mt-FTQTL6 (6 markers in total). Information regarding Mt-FTQTL6-linked markers is available in Additional file 1. The complete list for the rest of markers is available upon request. Similarly to RIL76, sister lines did not show heterozygosity for any of the background markers and were all homozygous carrying alleles from the freezing-sensitive parent at the freezing tolerance QTL on chromosomes 1 and 4. Five heterozygous recombinants at Mt-FTQTL6 were identified, namely 76-02, 76-05, 76-07, 76-08 and 76-09. Taking advantage of their heterozygosity for all markers associated with Mt-FTQTL6, 76-06 and 76-11 were selected for the construction of large segregating populations. Line 76-02 was also used for this purpose because it is only homozygous for two markers at the upper border of MtFTQTL6, namely NT6005 and NT6001 (Figure 1). F 6 populations that were obtained through self-pollination of 76-02, 76-06 and 76-11 comprised 447, 241 and 232 plants, respectively. Progenies were genotyped using 7 SNP and 6 SSR/indel markers located on both sides of marker MTIC153 (Additional file 1). For recombinant individuals, genotyping was further completed with 13 additional SNP markers (Additional file 1). A high-resolution linkage map constructed from a subset of marker data scored on 76-06 and 76-11 progenies is described in Tayeh et al. [39] (Additional file 2). $F_{5}$ and $F_{6}$ heterozygous recombinant individuals were self-pollinated. Homozygous $\left(\mathrm{F}_{6}\right.$ or $\left.\mathrm{F}_{7}\right)$ recombinants were selected from their progenies using corresponding markers. $\mathrm{F}_{7}$ and $\mathrm{F}_{8}$ plants were finally obtained through the self-pollination of homozygous recombinant plants and were submitted to freezing tolerance tests (Figure 1).

\section{Plant growth}

Seeds of M. truncatula were scarified using sand paper in order to rupture the seed coat. Scarified seeds were soaked in distilled water for 6 hours and spread on moistened filter papers in Petri dishes. After a 3-day dark storage at $6^{\circ} \mathrm{C}$ to break embryo dormancy and synchronize germination, Petri dishes were held at $20^{\circ} \mathrm{C}$ for three other days. Seedlings were then transplanted in $2 \mathrm{~L}$ pots containing a mix of peat and compost or in pre-moistened $41 \times 42-\mathrm{mm}$ jiffy-7 pellets (Jiffy France S.A.R.L., Trevoux, France), depending on the experimental need. In case of nongerminated seeds, especially when they were recently harvested, 3 to 5 parts per million of 2-chloroethylphosphonic acid were applied to Petri dishes to break embryo dormancy and seedlings were transplanted 24 hours later. Except for freezing tolerance tests, plants were finally left to grow in the greenhouse at an average temperature of 18/ $14^{\circ} \mathrm{C}$ (day/night) and a 16-hour photoperiod. Seeds were extracted from ripe pods using in most cases a homemade extraction system based on a rubber mat and a plaster hawk as described by Garcia et al. [87]. Large extractions were performed using a seed mill.

\section{Marker development and genotyping}

In addition to markers from Tayeh et al. [39], 8 new markers associated with Mt-FTQTL6 were developed in this study (Additional file 1). Primers were designed from BAC-end sequences using the Primer3 tool [88] with default parameters. Maximum product length was limited to $500 \mathrm{bp}$. Total genomic DNA was isolated from fresh leaflets harvested on one-month-old plants using Nucleospin 96 Plant II (Macherey Nagel, Germany) according to manufacturer's instructions. Genotyping of the plant material from this study with background and Mt-FTQTL6-associated markers was conducted as described in Tayeh et al. [39]. Capillary gel electrophoresis was employed for SSR and indel markers. The highresolution melting technique (in case of $\mathrm{F}_{7} / \mathrm{F}_{8}$ lines) and the competitive allele specific PCR method (in case of 447-plant 76-02-derived population) were used for SNP markers.

\section{Evaluation of freezing tolerance}

Freezing tolerance tests were performed in a climatecontrolled walk-in $2.6 \times 2.3 \times 2$ m growth chamber. Two experiments, consisting of two replications each, were carried out. Each replicate was composed of: (1) $F_{7}$ or $F_{8}$ plants carrying one (or two) recombination event(s) within Mt-FTQTL6-containing chromosomal region, (2) plants obtained from the same parental lines as the recombinant ones or from sister parental lines but that ideally do not have recombination events within Mt-FTQTL6 region and (3) parental accessions F83005-5 and DZA045-5 (Figure 1). Ten individuals from each of the above-cited lines were evaluated per replicate. Seedlings, transplanted in Jiffy pellets (see plant growth section), were placed in $10 \times 10$ well-containing homemade Styrodur plates to ensure root insulation. Four different phases were applied during each freezing tolerance test with the following environmental conditions: (1) nursery phase- 18 days: $20^{\circ} \mathrm{C} /$ $14^{\circ} \mathrm{C}$, 14-hour photoperiod and $250 \mu \mathrm{mol} . \mathrm{m}^{-2} . \mathrm{s}^{-1}$ photosynthetically active photon flux density (PPFD) provided by fluorescent lights; (2) cold acclimation phase-20 days: 
$8^{\circ} \mathrm{C} / 2^{\circ} \mathrm{C}$, 14-hour photoperiod and $250 \mu$ mol. $\mathrm{m}^{-2} . \mathrm{s}^{-1} \mathrm{PPFD}$; (3) freezing phase- 8 days: $4^{\circ} \mathrm{C} /-6^{\circ} \mathrm{C}, 10$-hour photoperiod and $150 \mu \mathrm{mol} . \mathrm{m}^{-2} . \mathrm{s}^{-1} \mathrm{PPFD}$; and (4) recovery phase-16 days: $16^{\circ} \mathrm{C} / 5^{\circ} \mathrm{C}$, 14-hour photoperiod and $250 \mu \mathrm{mol} . \mathrm{m}^{-2} . \mathrm{s}^{-1}$ PPFD. Continuous acquisition of chamber air temperature was carried out using a Campbell CR10x system equipped with a Humitter 50Y integrated humidity and temperature transmitter (Vaisala, Vantaa, Finland). Temperatures at leaf- and root- levels were also continuously surveyed using eight and four homemade T-type thermocouples connected to the acquisition system, respectively. Photosynthetically active radiation was checked twice per test phase by means of a LiCor 190SA quantum sensor (Licor Biosciences, Lincoln, Nebraska, USA). Irrigation was performed manually and stopped 2 days before and all along the freezing phase. Developmental stages were scored plant-by-plant six times during the nursery and cold acclimation phases. At the $16^{\text {th }}$ day of rewarming, plants were evaluated for freezing tolerance using a visual rating scale based on leaf injuries and ranging from 0 (no freezing injuries) to 5 (all leaflets are yellow and dry: dead plant). Plants were scored 1 when less than one quarter of the leaflets were visually damaged, 2 for one quarter of the leaflets being affected, 3 when freezing damage was observed on half of the leaflets and 4 when three-quarter of the leaflets were concerned. Pairwise comparisons of damage scores from recombinant, non-recombinant and parental lines were performed by one-way analysis of variance followed by a Tukey test at $P \leq 0.05$ using $R$ [89] (Figure 1). For each of these pairwise comparisons, the recombinant line and its non-recombinant counterpart(s) were compared between each other and with the closest plants of F83005-5 and DZA045-5 within the growth chamber.

\section{Full BAC sequencing}

BAC DNA was isolated using Nucleospin fast purification Kit (Macherey-Nagel, Düren, Germany). Full BAC sequencing was performed using 454 multiplexing technology on a GS-FLX Titanium sequencer (454 Life Sciences, Roche Diagnostics, Branford, Connecticut, USA). Raw reads were cleaned using PyroCleaner [90]. Reads sharing more than 95\% homology with BAC vector or Escherichia coli genome sequence were excluded. de novo assembly of the cleaned reads was performed using Newbler (version 2.3; 454 Life Sciences, Roche Diagnostics). The resulting contigs were, when possible, ordered and oriented based on marker sequences located therein. End sequences from overlapping BAC clones (Additional file 5) were used for the same purpose. Complementarily, end sequences of the different contigs were submitted to blastn/blastx [91] search against $M$. truncatula $\mathrm{nr} / \mathrm{nt}$, high-throughput genomic sequence, EST, genome survey sequence and protein databases in GenBank [36] at the National Center for Biotechnology Information. End sequences sharing more than $99 \%$ identity with the same target sequence(s) were considered as indicative of adjacent contigs.

\section{Sequencing of $C B F / D R E B 1$ genes from F83005-5 and DZA045-5}

The isolation and sequencing of $M t C B F 2-3 ; 5-14$ from F83005-5 and DZA045-5 was undertaken in order to determine if all genes composing the CBF/DREB1 cluster in A17 are similarly present in these accessions and to identify the polymorphism in the coding and immediate flanking sequences of these genes. Two to 3 specific forward and also 2 to 3 specific reverse primers were designed per gene. PCR were carried out using a touchdown protocol with the following thermal cycling conditions: 4 minutes at $94^{\circ} \mathrm{C} ; 5$ cycles at $94^{\circ} \mathrm{C}$ for 30 seconds, annealing temperature (Ta) $\left[-1^{\circ} \mathrm{C} /\right.$ cycle $]$ for 30 seconds, $72^{\circ} \mathrm{C}$ for 90 seconds; 35 cycles at $94^{\circ} \mathrm{C}$ for 30 seconds, $\left[\mathrm{Ta}-5^{\circ} \mathrm{C}\right]$ for 30 seconds, $72^{\circ} \mathrm{C}$ for 90 seconds; and 10 minutes at $72^{\circ} \mathrm{C}$. Different primer combinations and PCR conditions (Ta and/or $\mathrm{MgCl}_{2}$ concentration) were tested to optimize the amplification result. PCR products from the optimal conditions were purified from agarose gel using Nucleospin Extract II (Macherey-Nagel, Düren, Germany) following manufacturer's instructions and Sanger-sequenced using BigDye Terminator v3.1 chemistry (Applied Biosystems, Foster City, California, USA) on a 3130 $\times 1$ Genetic Analyzer (Hitachi/Applied Biosystems). Primers and amplification conditions that were used in the sequencing step are provided in Additional file 10. For 9 out of the 12 $C B F / D R E B 1$ genes, one or two internal primers were needed to ensure full sequence coverage and/or overcome sequencing difficulties caused by simple sequence repeats $\left[(\mathrm{A})_{\mathrm{n}}\right.$ or $\left.(\mathrm{T})_{\mathrm{n}}\right]$ present in $5^{\prime}$ - or $3^{\prime}$-non-coding flanking regions (Additional file 10). Base calling was performed with Sequencing Analysis Software (version 5.4; Applied Biosystems). Electropherograms were manually trimmed of poor sequence data.

\section{Availability of supporting data}

The data sets supporting the results of this article are included within the article and its additional files. All sequences were submitted to GenBank [36]. Insert sequences of BAC clones mth2-92O15, mte1-60A22 and mth2221P20 were deposited in the "high throughput genomic sequences" division under accession numbers KF00638284. BAC-end sequences were submitted to the "genome survey sequences" division and have been assigned the accession numbers JY974377-472. CBF/DREB1 gene sequences from A17, F83005-5 and DZA045-5 were deposited in the "plant, fungal, and algal sequences" division with accession numbers KC997199-225. 


\section{Additional files}

Additional file 1: List of markers used for plant material development and BAC clone contig map construction. Provides a list of the markers that were used for one or more of the following purposes: (1) genotyping of $\mathrm{F}_{6}$ segregating populations; (2) genotyping of $\mathrm{F}_{7} / \mathrm{F}_{8}$ lines used for Mt-FTQTL6 fine mapping; (3) synthesis of the PCR products used as probes for BAC filter screening and (4) validation of positive BAC clones and BAC contig construction. It includes primer sequences, PCR conditions and information on the type of polymorphism for corresponding markers.

Additional file 2: Genetic linkage map of Mt-FTQTL6 region. Contains a partial linkage map of $M$. truncatula chromosome 6 which was constructed using data collected on $453 \mathrm{~F}_{6}$ plants. It shows the relative positions of the different markers linked to Mt-FTQTL6 including MTIC153 and NT6054 that border its confidence interval.

Additional file 3: Construction of a BAC clone contig map spanning Mt-FTQTL6-containing region. Describes the strategy that was followed to close the physical gap coinciding with Mt-FTQTL6 and summarizes the main results. The text is organized in three sections: (1) State of art; (2) Methods and (3) Achievements.

Additional file 4: Positive PCR-confirmed BAC clones obtained through screening of high-density colony filters with 15 probes. Lists the BAC clones from M. truncatula mth2 and Mtf83 libraries that were identified by screening high-density colony filters with probes corresponding to $15 \mathrm{Mt}-\mathrm{FTQTL6}$-linked markers and were further confirmed positive by PCR control.

Additional file 5: BAC clone contigs partly spanning $M$. truncatula chromosome 6 region harboring Mt-FTQTL6. Depicts the six BAC clone contigs that were constructed with BAC clones identified either through screening of $M$. truncatula BAC libraries mth2 and Mtf83 (see Additional file 4) or using an in silico approach. The BAC clone contig map is connected to the genetic map of Mt-FTQTL6 by means of the 15 markers used as screening probes and other additional markers. The three BAC clones that were selected for insert sequencing are shown.

Additional file 6: Statistics of 454 BAC sequencing and contig assembly. Contains information relative to 454 sequencing of BAC clones mth2-92015, mte1-60A22 and mth2-221P20. Statistics on raw, cleaned and assembled sequences are given.

Additional file 7: Colinearity conservation between Mt-FTQTL6 interval and chromosomal regions from sequenced dicotyledonous genomes. Illustrates colinearity conservation between Mt-FTQTL6 region and different genomic segments from reference dicotyledonous plant species including M. truncatula, G. max, L. japonicus, P. trichocarpa, A. thaliana, V. vinifera and S. lycopersicum.

Additional file 8: Pairwise comparison of predicted protein products of $M t C B F 2-3 ; 5-10 ; 12-14$. Shows amino acid identity and similarity between the predicted protein products of MtCBF2-3;5-10;12-14. This information is important to understand the phylogenetic relationships between tandemly duplicated CBF/DREB1 genes

Additional file 9: Amino acid variants within CBF/DREB1 signature sequences. Reports the amino acid variants in conserved CBF/DREB1 signature motifs PKKP/RAGRxKFxETRHP, DSAWR, A(AN)xxA(AN)xxF and LWSY that are carried by MtCBF2-3;5-11;14. Other CBF/DREB1 proteins sharing the same amino acid variant(s) are indicated when possible.

Additional file 10: Sequencing of MtCBF2-3;5-12;14: primers, PCR conditions and sequence analyses. Contains details on the primers that were used to isolate and sequence MtCBF2-3;5-12;14 from F83005-5 and DZA045-5. For each of the CBF/DREB1 genes, SNP, indel and SSR polymorphisms identified between F83005-5 and DZA045-5 together with amino acid variations amongst the predicted protein products are indicated.

Additional file 11: Bibliographic review regarding non-CBF/DREB1 candidate genes for Mt-FTQTL6. Briefly reviews the current knowledge on non-CBF/DREB1positional candidate genes for Mt-FTQTL6 and particularly their functions. Information is available for MtBAG-1, MtPERLD, MTR_050s0020,
MtZFWD, MTR_054s0001 and MTR_05450019 whereas no data could be obtained for MTR_050s0019 and MTR_69089580.

Additional file 12: Expression profiles of a subset of $M$. truncatula CBF/DREB1 genes according to the Gene Expression Atlas. Shows the mean transcript levels from three independent biological replicates of MtCBF2, MtCBF3, MtCBF5, MtCBF6, MtCBF7, MtCBF8.1, MtCBF8.2 and MtCBF9 in four unstressed organs (root, stem, leaf and flower) of the A17 accession. Data were obtained from M. truncatula Gene Expression Atlas version 2 [76].

\section{Abbreviations}

BAC: Bacterial-artificial chromosome; CBF: C-repeat binding factor; DREB1: Dehydration-responsive element binding factor 1; QTL: Quantitative trait locus; WGS: Whole-genome shotgun; GBacc: GenBank accession number; FDS: Freezing damage score; $\mathrm{nr} / \mathrm{nt}$ : Non-redundant nucleotide; EST: Expressed sequence tag; CDNA: Complementary DNA; SNP: Single nucleotide polymorphism; indel: Insertion-deletion; SSR: Simple sequence repeat; pl: Isoelectric point; SINE: Short interspersed nuclear element; RIL: Recombinant inbred line; PPFD: Photosynthetically active photon flux density; Ta: Annealing temperature.

\section{Competing interests}

The authors declare that they have no competing interests.

\section{Authors' contributions}

NT developed genetic markers, genotyped plant material, constructed the BAC clone contig map, analyzed generated sequences, designed primers for the isolation of the CBF/DREB1 genes and wrote the manuscript. HS and NB set up phenotyping experiments and analyzed scored data. $A B$ isolated and sequenced CBF/DREB1 genes. CB contributed to CBF/DREB1 sequencing and to $P C R$ validation of positive $B A C$ clones. JF and $A r B$ performed hybridization of $M$. truncatula BAC libraries, generated BAC-end sequences and prepared BAC clones for full-insert sequencing. FD assembled WGS sequences and provided contig sequences spanning Mt-FTQTL6 interval. ILH, BD and NB contributed to conception and design of the study, managed the technical and financial supplies of the project and reviewed the manuscript. All authors approved the current version of the manuscript.

\section{Acknowledgments}

The authors wish to thank Dr. Jean-Marie Prosperi for providing $F_{6}$ plants from which $\mathrm{F}_{7}$ and $\mathrm{F}_{8}$ recombinant lines were obtained, Rosemonde Devaux for plant care in the greenhouse and Frédéric Depta and Jean-François Hû for assistance in the conduct of freezing tolerance experiments. They acknowledge Dr. Hélène Bergès for helpful discussions concerning BAC clone isolation and sequencing. The authors would also like to thank the reviewers and the editor for their helpful comments which improved the manuscript. This work was partially financially supported by the Région Nord Pas-de-Calais - France (FEDER ARCIR PLANTEQ3 program) and by the Union Nationale Interprofessionnelle des plantes riches en Protéines (UNIP - SAMPOIS program). NT was the recipient of a Ph.D. fellowship from the 'Ministère de l'Enseignement Supérieur et de la Recherche' - France.

\section{Author details}

'Université Lille 1, UMR 1281 Stress Abiotiques et Différenciation des Végétaux cultivés (SADV), Bâtiment SN2, F-59655 Villeneuve d'Ascq Cedex, France. ${ }^{2}$ INRA, UMR 1281 Stress Abiotiques et Différenciation des Végétaux cultivés (SADV), Estrées-Mons, BP 50136, F-80203 Péronne Cedex, France. ${ }^{3}$ INRA, Centre National de Ressources Génomiques Végétales (CNRGV), BP 52627, F-31326 Castanet-Tolosan Cedex, France. ${ }^{4}$ INRA/CNRS, UMR 441/2594, Laboratoire des Interactions Plantes-Microorganismes (LIPM), BP 52627, F-31326 Castanet-Tolosan Cedex, France.

Received: 19 July 2013 Accepted: 4 November 2013 Published: 21 November 2013

\section{References}

1. Ruelland E, Vaultier MN, Zachowski A, Hurry V: Cold signalling and cold acclimation in plants. Adv Bot Res 2009, 49:35-146.

2. Guy CL: Cold acclimation and freezing stress tolerance: role of protein metabolism. Annu Rev Plant Physiol Plant Mol Biol 1990, 41:187-223. 
3. Thomashow MF: Plant cold acclimation, freezing tolerance genes and regulatory mechanisms. Annu Rev Plant Physiol Plant Mol Biol 1999, 50:571-599.

4. Thomashow MF: Molecular basis of plant cold acclimation: insights gained from studying the CBF cold response pathway. Plant Physiol 2010, 154:571-577.

5. Stockinger EJ, Gilmour SJ, Thomashow MF: Arabidopsis thaliana CBF1 encodes an AP2 domain-containing transcriptional activator that binds to the $C$ repeat/DRE, a cis-acting DNA regulatory element that stimulates transcription in response to low temperature and water deficit. Proc Natl Acad Sci U S A 1997, 94:1035-1040.

6. Liu Q, Kasuga M, Sakuma Y, Abe H, Miura S, Yamaguchi-Shinozaki K Shinozaki K: Two transcription factors, DREB1 and DREB2, with an EREBP/AP2 DNA binding domain separate two cellular signal transduction pathways in drought- and low-temperature-responsive gene expression, respectively, in Arabidopsis. Plant Cell 1998, 10:1391-1406.

7. Gilmour SJ, Zarka DG, Stockinger EJ, Salazar MP, Houghton JM, Thomashow MF: Low temperature regulation of Arabidopsis CBF family of AP2 transcriptional activators as an early step in cold-induced COR gene expression. Plant J 1998, 16:433-442.

8. Jaglo KR, Kleff S, Amundsen KL, Zhang X, Haake V, Zhang JZ, Deits T, Thomashow MF: Components of the Arabidopsis C-repeat/ dehydration-responsive element binding factor cold-response pathway are conserved in Brassica napus and other plant species. Plant Physiol 2001, 127:910-917.

9. Benedict C, Skinner JS, Meng R, Chang Y, Bhalerao R, Huner NPA, Finn CE, Chen $\mathrm{THH}$, Hurry $\mathrm{V}$ : The CBF1-dependent low temperature signalling pathway, regulon and increase in freeze tolerance are conserved in Populus spp. Plant Cell Environ 2006, 29:1259-1272.

10. Tamura K, Yamada T: A perennial ryegrass CBF gene cluster is located in a region predicted by conserved synteny between Poaceae species. Theor Appl Genet 2007, 114:273-283.

11. Xiao H, Tattersall EAR, Siddiqua MK, Cramer GR, Nassuth A: CBF4 is a unique member of the CBF transcription factor family of Vitis vinifera and Vitis riparia. Plant Cell Environ 2008, 31:1-10.

12. Gilmour SJ, Sebolt AM, Salazar MP, Everard JD, Thomashow MF: Overexpression of the Arabidopsis CBF3 transcriptional activator mimics multiple biochemical changes associated with cold acclimation. Plant Physiol 2000, 124:1854-1865.

13. Gilmour SJ, Fowler SG, Thomashow MF: Arabidopsis transcriptional activators $\mathrm{CBF} 1, \mathrm{CBF} 2$, and $\mathrm{CBF} 3$ have matching functional activities. Plant Mol Biol 2004, 54:767-781.

14. Chen JR, Lü JJ, Liu R, Xiong XY, Wang TX, Chen SY, Guo LB, Wang HF: DREB1C from Medicago truncatula enhances freezing tolerance in transgenic M. truncatula and China Rose (Rosa chinensis Jacq.). Plant Growth Regul 2010, 60:199-211.

15. Navarro M, Ayax C, Martinez Y, Laur J, El Kayal W, Marque C, Teulières C: Two EguCBF1 genes overexpressed in Eucalyptus display a different impact on stress tolerance and plant development. Plant Biotechnol J 2011, 9:50-63.

16. Tillett RL, Wheatley MD, Tattersall EAR, Schlauch KA, Cramer GR, Cushman JC: The Vitis vinifera $\mathrm{C}$-repeat binding protein 4 (VvCBF4) transcriptional factor enhances freezing tolerance in wine grape. Plant Biotechnol J 2012, 10:105-124.

17. Graham PH, Vance CP: Legumes: importance and constraints to greater use. Plant Physiol 2003, 131:872-877.

18. Doyle JJ, Luckow MA: The rest of the iceberg. Legume diversity and evolution in a phylogenetic context. Plant Physiol 2003, 131:900-910

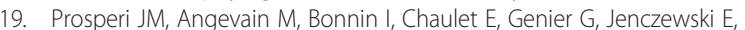
Olivieri I, Ronfort J: Genetic diversity, preservation and use of genetic resources of Mediterranean legumes: alfalfa and medics. Cah Options Mediterr 1996, 18:71-89.

20. Nichols PGH, Loi A, Nutt BJ, Evans PM, Craig AD, Pengelly BC, Dear BS, Loyd DL, Revell CK, Nair RM, Ewing MA, Howieson JG, Auricht GA, Howie JH, Sandral GA, Carr SJ, de Koning CT, Hackney BF, Crocker GJ, Snowball R, Hughes SJ, Hall EJ, Foster KJ, Skinner PW, Barbetti MJ, You MP: New annual and short-lived perennial pasture legumes for Australian agriculture - 15 years of revolution. Field Crops Res 2007, 104:10-23.

21. Cook DR: Medicago truncatula-a model in the making! Curr Opin Plant Biol 1999, 2:301-304

22. Young ND, Udvardi M: Translating Medicago truncatula genomics to crop legumes. Curr Opin Plant Biol 2009, 12:193-201.
23. Young ND, Debellé F, Oldroyd GED, Geurts R, Cannon SB, Udvardi MK, Benedito VA, Mayer KFX, Gouzy J, Schoof H, Van de Peer Y, Proost S, Cook DR, Meyers BC, Spannagl M, Cheung F, De Mita S, Krishnakumar V, Gundlach H, Zhou S, Mudge J, Bharti AK, Murray JD, Naoumkina MA, Rosen B, Silverstein KAT, Tang H, Rombauts S, Zhao PX, Zhou P, et al: The Medicago genome provides insight into the evolution of rhizobial symbioses. Nature 2011, 480:520-524.

24. Choi HK, Mun JH, Kim DJ, Zhu H, Baek JM, Mudge J, Roe B, Ellis N, Doyle J, Kiss GB, Young ND, Cook DR: Estimating genome conservation between crop and model legume species. Proc Natl Acad Sci USA 2004, 101:15289-15294.

25. Choi HK, Kim D, Uhm T, Limpens E, Lim H, Mun JH, Kalo P, Penmetsa RV, Seres A, Kulikova O, Roe BA, Bisseling T, Kiss GB, Cook DR: A sequence-based genetic map of Medicago truncatula and comparison of marker colinearity with M. sativa. Genetics 2004, 166:1463-1502.

26. Sato S, Isobe S, Asamizu E, Ohmido N, Kataoka R, Nakamura Y, Kaneko T, Sakurai N, Okumura K, Klimenko I, Sasamoto S, Wada T, Watanabe A, Kohara M, Fujishiro T, Tabata S: Comprehensive structural analysis of the genome of red clover (Trifolium pratense L.). DNA Res 2006, 12:301-364.

27. Phan HTT, Ellwood SR, Hane JK, Ford R, Materne M, Oliver RP: Extensive macrosynteny between Medicago truncatula and Lens culinaris ssp. culinaris. Theor App/ Genet 2007, 114:549-558.

28. Bordat A, Savois V, Nicolas M, Salse J, Chauveau A, Bourgeois M, Potier J, Houtin $\mathrm{H}$, Rond $\mathrm{C}$, Murat F, Marget $\mathrm{P}$, Aubert G, Burstin J: Translational genomics in legumes allowed placing in silico 5460 unigenes on the pea functional map and identified candidate genes in Pisum sativum L. Genes Genome Genet 2011, 1:93-103.

29. Bounejmate M, LosS SP, Robson AD: Effects of temperature and frost on genotypes of Medicago truncatula L. and Medicago aculeate L. from contrasting climatic origins. J Agro Crop Sci 1994, 172:227-236.

30. Antolín MC, Hekneby M, Sánchez-Díaz M: Contrasting responses of photosynthesis at low temperatures in different legume species. Photosynthetica 2005, 43:65-74.

31. Hekneby M, Antolín MC, Sánchez-Díaz M: Frost resistance and biochemical changes during cold acclimation in different annual legumes. Env Exp Bot 2006, 55:305-314.

32. Pennycooke JC, Cheng H, Stockinger EJ: Comparative genomic sequence and expression analyses of Medicago truncatula and alfalfa subspecies falcata cold acclimation-specific genes. Plant Physiol 2008, 146:1242-1254.

33. Thapa B, Arora R, Knapp AD, Brummer EC: Applying freezing test to quantify cold acclimation in Medicago truncatula. J Amer Soc Hort Sci 2008, 133:684-691.

34. Zhang LL, Zhao MG, Tian QY, Zhang WH: Comparative studies on tolerance of Medicago truncatula and Medicago falcata to freezing. Planta 2011, 234:445-457.

35. Li D, Zhang Y, Hu X, Shen X, Ma L, Su Z, Wang T, Dong J: Transcriptional profiling of Medicago truncatula under salt stress identified a novel CBF transcription factor MtCBF4 that plays an important role in abiotic stress responses. BMC Plant Biol 2011, 11:109.

36. Benson DA, Karsch-Mizrachi I, Lipman DJ, Ostell J, Wheeler DL: GenBank Nucleic Acids Res 2005, 33:D34-D38.

37. Zhang Z, Zhou Q, Yang Z, Jiang J: Discovery AP2/ERF family genes in silico in Medicago truncatula. African J Biotech 2013, 12:3636-3642.

38. Avia K, Pilet-Nayel ML, Bahrman N, Baranger A, Delbreil B, Fontaine V, Hamon C, Hanocq E, Niarquin M, Sellier H, Vuylsteker C, Prosperi JM, Lejeune-Hénaut I: Genetic variability and QTL mapping of freezing tolerance and related traits in Medicago truncatula. Theor Appl Genet 2013, 126:2353-2366.

39. Tayeh N, Bahrman N, Devaux R, Bluteau A, Prosperi JM, Delbreil B, Lejeune-Hénaut I: A high-density genetic map of the Medicago truncatula major freezing tolerance QTL on chromosome 6 reveals colinearity with a QTL related to freezing damage on Pisum sativum linkage group VI. Mol Breeding 2013, 32:279-289.

40. Yan J, He C, Zhang H: The BAG-family proteins in Arabidopsis thaliana. Plant Sci 2003, 165:1-7.

41. Skinner JS, von Zitzewitz J, Szücs P, Marquez-Cedillo L, Filichkin T, Amundsen K, Stockinger EJ, Thomashow MF, Chen THH, Hayes PM: Structural, functional, and phylogenetic characterization of a large CBF gene family in barley. Plant Mol Biol 2005, 59:533-551.

42. Jofuku KD, den Boer BG, Van Montagu M, Okamuro JK: Control of Arabidopsis flower and seed development by the homeotic gene APETALA2. Plant Cell 1994, 6:1211-1225. 
43. Ohme-Takagi M, Shinshi $\mathrm{H}$ : Ethylene-inducible DNA binding proteins that interact with an ethylene-responsive element. Plant Cell 1995, 7:173-182.

44. Canella D, Gilmour SJ, Kuhn LA, Thomashow MF: DNA binding by the Arabidopsis CBF1 transcription factor requires the PKKP/RAGRxKFxETRHP signature sequence. Biochem Biophys Acta 2010, 1799:454-462.

45. Wang Z, Triezenberg SJ, Thomashow MF, Stockinger EJ: Multiple hydrophobic motifs in Arabidopsis CBF1 COOH-terminus provide functional redundancy in trans-activation. Plant Mol Biol 2005, 58:543-559.

46. Xiong Y, Fei SZ: Functional and phylogenetic analysis of a DREB/CBF-like gene in perennial ryegrass (Lolium perenne L.). Planta 2006, 224:878-888.

47. Dubouzet JG, Sakuma Y, Ito Y, Kasuga M, Dubouzet EG, Miura S, Seki M, Shinozaki K, Yamaguchi-Shinozaki K: OsDREB genes in rice, Oryza sativa L., encode transcription activators that function in drought-, high-salt- and cold-responsive gene expression. Plant J 2003, 33:751-763.

48. Sakuma Y, Qiang L, Dubouzet JG, Abe H, Shinozaki K, Yamaguchi-Shinozaki K: DNA-binding specificity of the ERF/AP2 domain of Arabidopsis DREBs, transcription factors involved in dehydration- and cold-inducible gene expression. Biochem Biophys Res Commun 2002, 290:998-1009.

49. Zhang G, Chen M, Chen X, Xu Z, Guan S, Li LC, Li A, Guo J, Mao L, Ma Y: Phylogeny, gene structures, and expression patterns of the ERF gene family in soybean (Glycine max L.). J Exp Bot 2008, 59:4095-4107.

50. Allen MD, Yamasaki K, Ohme-Takagi M, Tateno M, Suzuki M: A novel mode of DNA recognition by a b-sheet revealed by the solution structure of the GCC-box binding domain in complex with DNA. EMBO J 1998, 17:5484-5496.

51. Doukhanina EV, Chen S, Van Der Zalm E, Godzik A, Reed J, Dickman MB: Identification and functional characterization of the BAG protein family in Arabidopsis thaliana. J Biol Chem 2006, 281:18793-18801.

52. Nosarzewski M, Downie AB, Wu B, Archbold DD: The role of sorbitol dehydrogenase in Arabidopsis thaliana. Fun Plant Biol 2012, 39:462-470.

53. Betti M, Petrucco S, Bolchi A, Dieci G, Ottonello S: A plant 3'phosphoesterase involved in the repair of DNA strand breaks generated by oxidative damage. J Biol Chem 2001, 276:18038-18045.

54. Petrucco S, Volpi G, Bolchi A, Rivetti C, Ottonello S: A nick-sensing DNA 3'-repair enzyme from Arabidopsis. J Biol Chem 2002, 277:23675-23683.

55. Fujita $M$, Umemura $M$, Yoko-o $T$, Jigami Y: PER1 is required for GPI-phospholipase A2 activity and involved in lipid remodeling of GPI-anchored proteins. Mol Biol Cell 2006, 17:5253-5264.

56. Sánchez-Fernández R, Davies TGE, Coleman JOD, Rea PA: The Arabidopsis thaliana $\mathrm{ABC}$ protein superfamily, a complete inventory. J Biol Chem 2001, 276:30231-30244.

57. Garcia O, Bouige P, Forestier C, Dassa E: Inventory and comparative analysis of rice and Arabidopsis ATP-binding cassette (ABC) systems. J Mol Biol 2004, 343:249-265.

58. Terol J, Bargues M, Pérez-Alonso M: ZFWD: a novel subfamily of plant proteins containing a $\mathrm{C} 3 \mathrm{H}$ zinc finger and seven WD40 repeats. Gene 2000, 260:45-53.

59. Alonso-Blanco C, Gomez-Mena C, Llorente F, Koornneef M, Salinas J, Martinez-Zapater JM: Genetic and molecular analyses of natural variation indicate CBF2 as a candidate gene for underlying a freezing tolerance quantitative trait locus in Arabidopsis. Plant Physiol 2005, 139:1304-1312.

60. Gery C, Zuther E, Schulz E, Legoupi J, Chauveau A, McKhann H, Hincha DK, Téoulé E: Natural variation in the freezing tolerance of Arabidopsis thaliana: Effects of RNAi-induced CBF depletion and QTL localisation vary among accessions. Plant Sci 2011, 180:12-23.

61. Vágújfalvi A, Galiba G, Cattivelli L, Dubcovsky J: The cold regulated transcriptional activator $\mathrm{Cbf3}$ is linked to the frost tolerance locus Fr-A2 on wheat chromosome 5A. Mol Gen Genome 2003, 269:60-67.

62. Båga M, Chodaparambil SV, Limin AE, Pecar M, Fowler DB, Chibbar RN: Identification of quantitative trait loci and associated candidate genes for low-temperature tolerance in cold-hardy winter wheat. Fun Integr Genomics 2007, 7:53-68.

63. Francia E, Rizza F, Cattivelli L, Stanca AM, Galiba G, Tóth B, Hayes PM, Skinner JS, Pecchioni N: Two loci on chromosome $5 \mathrm{H}$ determine low-temperature tolerance in a 'Nure' (winter) x 'Tremois' (spring) barley map. Theor Appl Genet 2004, 108:670-680.

64. Rizzon C, Ponger L, Gaut BS: Striking similarities in the genomic distribution of tandemly arrayed genes in Arabidopsis and rice. PLoS Comput Biol 2006, 2:e115.

65. Wang $Y$, Wang $X$, Paterson AH: Genome and gene duplications and gene expression divergence: a view from plants. Ann NY Acad Sci 2012, 1256:1-14.
66. Ameline-Torregrosa C, Wang BB, O'Bleness MS, Deshpande S, Zhu H, Roe B, Young ND, Cannon SB: Identification and characterization of nucleotide-binding site-leucine-rich repeat genes in the model plant Medicago truncatula. Plant Physiol 2008, 146:5-21.

67. Shin JH, Van K, Kim DH, Kim KD, Jang YE, Choi BS, Kim MY, Lee SH: The lipoxygenase gene family: a genomic fossil of shared polyploidy between Glycine max and Medicago truncatula. BMC Plant Bio 2008, 8:133.

68. Azar S, SanClemente H, Marque G, Dunand C, Marque C, Teulieres C: Bioinformatic prediction of the AP2/ERF family genes in Eucalyptus grandis: focus on the CBF family. BMC Proc 2011, 5(Suppl7):165.

69. Freeling M: Bias in plant gene content following different sorts of duplication: tandem, whole-genome, segmental, or by transposition. Annu Rev Plant Biol 2009, 60:433-453.

70. Hanikenne M, Talke IN, Haydon MJ, Lanz C, Nolte A, Motte P, Kroymann J, Weigel $D$, Krämer $U$ : Evolution of metal hyperaccumulation required cis-regulatory changes and triplication of HMA4. Nature 2008, 453:391-395.

71. Himmelbach A, Liu L, Zierold U, Altschmied L, Maucher H, Beier F, Müller D, Hensel G, Heise A, Schützendübel A, Kumlehn J, Schweizera P: Promoters of the barley germin-like GER4 gene cluster enable strong transgene expression in response to pathogen attack. Plant Cell 2010, 22:937-952.

72. Yamaguchi-Shinozaki K, Shinozaki K: A novel cis-acting element in an Arabidopsis gene is involved in responsiveness to drought, low-temperature, or high-salt stress. Plant Cell 1994, 6:251-264.

73. Kliebenstein DJ, Lambrix VM, Reichelt M, Gershenzon J, Mitchell-Olds T: Gene duplication in the diversification of secondary metabolism: tandem 2-Oxoglutarate-dependent dioxygenases control glucosinolate biosynthesis in Arabidopsis. Plant Cell 2001, 13:681-693.

74. Xu K, Xu X, Fukao T, Canlas P, Maghirang-Rodriguez R, Heuer S, Ismail AM, Bailey-Serres J, Ronald PC, Mackill DJ: Sub1A is an ethylene-response-factor-like gene that confers submergence tolerance to rice. Nature 2006, 442:705-708.

75. Rampino P, Mita G, Assab E, De Pascali M, Giangrande E, Treglia AS, Perrotta C: Two sunflower 17.6HSP genes, arranged in tandem and highly homologous, are induced differently by various elicitors. Plant Biol 2010, 12:13-22.

76. Benedito VA, Torres-Jerez I, Murray JD, Andriankaja A, Allen S, Kakar K, Wandrey M, Verdier J, Zuber H, Ott T, Moreau S, Niebel A, Frickey T, Weiller G, He J, Dai X, Zhao PX, Tang Y, Udvardi MK: A gene expression atlas of the model legume Medicago truncatula. Plant J 2008, 55:504-513.

77. Novillo F, Medina J, Salinas J: Arabidopsis CBF1 and CBF3 have a different function than CBF2 in cold acclimation and define different gene classes in the CBF regulon. Proc Natl Acad Sci U S A 2007, 104:21002-21007.

78. Vágújfalvi A, Aprile A, Miller A, Dubcovsky J, Delugu G, Galiba G, Cattivelli L: The expression of several $C b f$ genes at the $F r-A 2$ locus is linked to frost resistance in wheat. Mol Genet Genom 2005, 274:506-514.

79. Zhang PG, Huang SZ, Pin AL, Adams KL: Extensive divergence in alternative splicing patterns after gene and genome duplication during the evolutionary history of Arabidopsis. Mol Biol Evol 2010, 27:1686-1697.

80. Xue GP, Loveridge CW: HvDRF1 is involved in abscisic acid-mediated gene regulation in barley and produces two forms of AP2 transcriptional activators, interacting preferably with a CT-rich element. Plant J 2004, 37:326-339.

81. Qin F, Kakimoto M, Sakuma Y, Maruyama K, Osakabe Y, Phan Tran LS, Shinozaki K, Yamaguchi-Shinozaki K: Regulation and functional analysis of ZmDREB2A in response to drought and heat stresses in Zea mays $\mathrm{L}$. Plant J 2007, 50:54-69.

82. Matsukura S, Mizoi J, Yoshida T, Todaka D, Ito Y, Maruyama K, Shinozaki K, Yamaguchi-Shinozaki K: Comprehensive analysis of rice DREB2-type genes that encode transcription factors involved in the expression of abiotic stress-responsive genes. Mol Genet Genom 2010, 283:185-196.

83. Saqib M, Ellwood SR, Jones RAC, Jones MGK: Resistance to Subterranean clover mottle virus in Medicago truncatula and genetic mapping of a resistance locus. Crop Pasture Sci 2009, 60:480-489.

84. Julier B, Huguet T, Chardon F, Ayadi R, Pierre JB, Prosperi JM, Barre P, Huyghe $C$ : Identification of quantitative trait loci influencing aerial morphogenesis in the model legume Medicago truncatula. Theor Appl Genet 2007, 114:1391-1406.

85. INRA BRC-MTR: Biological Resource Centre for the model species Medicago truncatula. http://www1.montpellier.inra.fr/BRC-MTR.

86. Ronfort J, Bataillon T, Santoni S, Delalande M, David JL, Prosperi JM: Microsatellite diversity and broad scale geographic structure in a model 
legume: building a set of nested core collection for studying naturally occurring variation in Medicago truncatula. BMC Plant Biol 2006, 6:28.

87. Garcia J, Barker DG, Journet EP: Seed storage and germination. http://www. noble.org/Global/medicagohandbook/pdf/SeedStorage_Germination.pdf.

88. Rozen S, Skaletsky HJ: Primer3 on the WWW for general users and for biologist programmers. In Bioinformatics methods and protocols: methods in molecular biology. Edited by Krawetz S, Misener S. New Jersey: Humana Press; 2000:365-386.

89. The R Project for Statistical Computing. [http://www.r-project.org]

90. Mariette J, Noirot C, Klopp C: Assessment of replicate bias in 454 pyrosequencing and a multi-purpose read-filtering tool. BMC Res Notes 2011, 4:149.

91. Altschul SF, Gish W, Miller W, Myers EW, Lipman DJ: Basic local alignment search tool. J Mol Biol 1990, 215:403-410.

doi:10.1186/1471-2164-14-814

Cite this article as: Tayeh et al: A tandem array of CBF/DREB1 genes is

located in a major freezing tolerance QTL region on Medicago

truncatula chromosome 6. BMC Genomics 2013 14:814.

\section{Submit your next manuscript to BioMed Central and take full advantage of:}

- Convenient online submission

- Thorough peer review

- No space constraints or color figure charges

- Immediate publication on acceptance

- Inclusion in PubMed, CAS, Scopus and Google Scholar

- Research which is freely available for redistribution 